\title{
Current Experience and Future Challenges of COVID-19 in Sri Lanka: An Auto-Ethnographic Study
}

\author{
${ }^{1}$ University of Toronto, Canada \\ ${ }^{2}$ Hospital for Sick Children, Canada \\ ${ }^{3}$ University of Colombo, Sri Lanka \\ ${ }^{4}$ Ministry of Health, Sri Lanka
}

Ratnapalan $S^{1,2 *}$, Perera $\mathbf{N}^{2,3}$, Wei $\mathbf{X}^{1}$, Samaraweera $S^{4}$, Nandasena $S^{4}$, Liyanage $\mathrm{P}^{4}$, Fernando RMSD ${ }^{4}$ and Dabrera TME ${ }^{4}$

\section{Research Article \\ Volume 5 Issue 1}

Received Date: December 24, 2020

Published Date: February 01, 2021

DOI: $10.23880 /$ phoa-16000173

*Corresponding author: Savithiri Ratnapalan, Department of Paediatrics, Dalla Lana School of Public Health, University of Toronto, Toronto, Ontario M5G 1X8, Canada, Tel: 416-813-7532; Fax: 416-813-5043; Email: savithiri.ratnapalan@sickkids.ca

\section{Abstract}

Purpose: Sri Lanka a Lower Middle Income Country (LMIC) has focussed mainly on public health measures to contain COVID-19 pandemic. The objective of this paper is to describe the efforts undertaken in Sri Lanka to manage COVID-19 pandemic and to learn from shared experiences.

Methods: This study was conducted as an auto-ethnographic study. Narrative accounts of key team members of Sri Lanka's pandemic management teams were synthesized into a master narrative.

Results: Authors' experiences are described below under the following themes: Surveillance and public health actions, test, isolate and trace strategy, infection prevention and control strategy, communication strategies and challenges. Sri Lanka adopted a screen and quarantine policy for all arrivals after the first patient and identified high risk areas. Polymerase-ChainReaction (PCR) testing capacity was achieved rapidly. All potential patients were tested and isolated if positive regardless of symptoms. Aggressive contact tracing was undertaken, Hospitals and other institutions were remodified to accommodate and isolate all COVID-19 positive cases. Quarantine centers were created when home quarantine was unsatisfactory and mobility restrictions were placed and expanded as lockdowns or curfews. Communication channels were developed for healthcare workers, other public sectors and the community. Extensive collaboration and community support helped to mitigate some of the challenges.

Conclusion: Sri Lanka was able to confine COVID-19 to population clusters using the 'test, isolate and trace' policy. There is concern regarding the long term feasibility of this policy, the economic impact of lockdowns and the threat for rapid spread on relaxing current public health measures.

Keywords: COVID-19; Pandemic Management; Contact Tracing; Isolation; Quarantine; Public Health

$>$ What we already know

- COVID 19 can spread from asymptomatic person.

- Quarantine centers for isolating suspected patients are not practiced in many countries and they advocate for home quarantine despite the risk of household spread.

- COVID-19 pandemic can be devastating to low middle income countries due to their constrained health care systems
$>$ What this article adds

- Isolating all positive patients regardless of symptoms can curb community spread of COVID 19

- Home quarantine may not be practical in low middle income countries and quarantine centers can be established in collaboration with other public health services such as the military in low middle income countries. 
- COVID-19 pandemic was contained to population clusters in low middle income country using an aggressive test, isolate and trace policy.

Abbreviations: MOH: Medical Officers of Health; PHI: Public Health Inspectors; PHM: Public Health Midwifes.

\section{Introduction}

World Health Organization (WHO) published its first report on January 5, 2020 about an outbreak of a novel viral pneumonia in Wuhan, China which continues to spread across the world with devastating effects [1]. Sri Lanka is an island $(62,705 \mathrm{~km} 2)$ in the Indian Ocean 4,445 $\mathrm{km}$ away from Wuhan, with population of 21.5 million. The country is divided into 25 districts under 9 provinces and has universal free health services. The Public health section delivers services through field health teams. Public health physicians called the Medical Officers of Health (MOH) and their field team consisting of 6-7 Public Health Inspectors (PHI) and 25-30 Public Health Midwifes (PHM), serve areas that geographically coincide with administrative boundaries of the Divisional Secretariat areas of the country [2]. China is heavily invested in infrastructure development in Sri Lanka and approximately 30,000 employment visas were issued or renewed for Chinese workers in 2017 [3]. In 2018, 280,000 tourists from China visited Sri Lanka and by August 2019 [4], 4,000 tourists from across the globe were arriving daily. On
January 27, 2020, Sri Lanka reported a 42 year-old lady from Wuhan as the first confirmed case of Coronavirus [5]. By the end of September 3313 positive persons and 13 deaths have been reported in Sri Lanka [6]. Please see Figure 1 for number of COVID-19 cases by provinces on September 30, 2020 and Figure 2 for the epidemic graph from January to September 2020 [7].

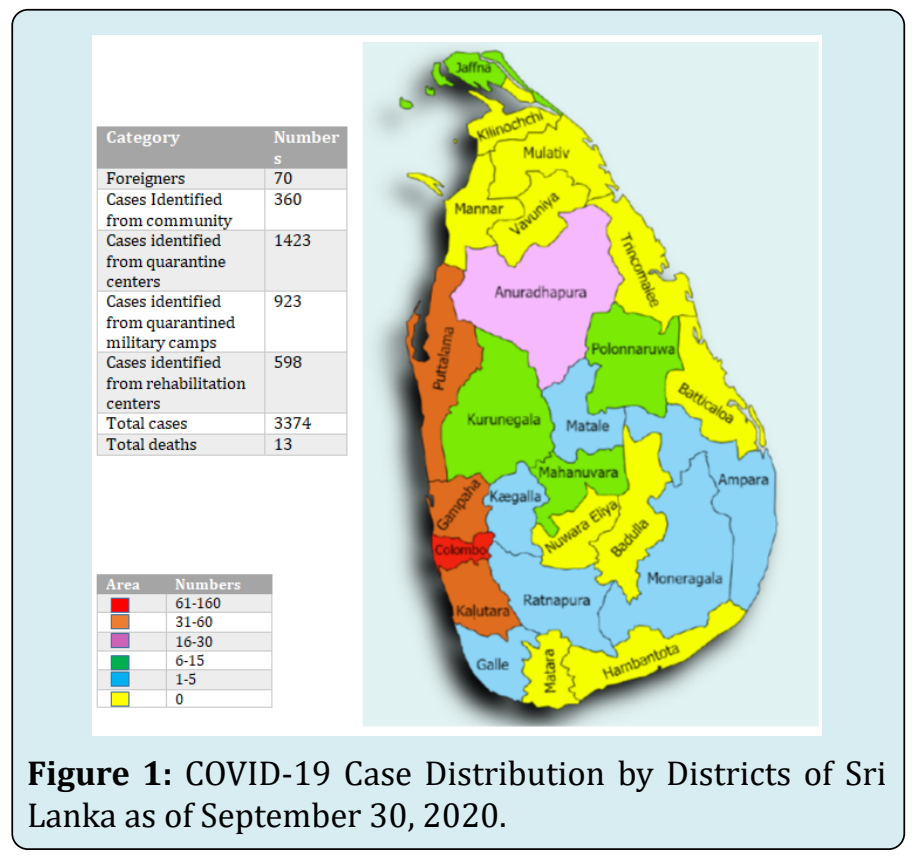

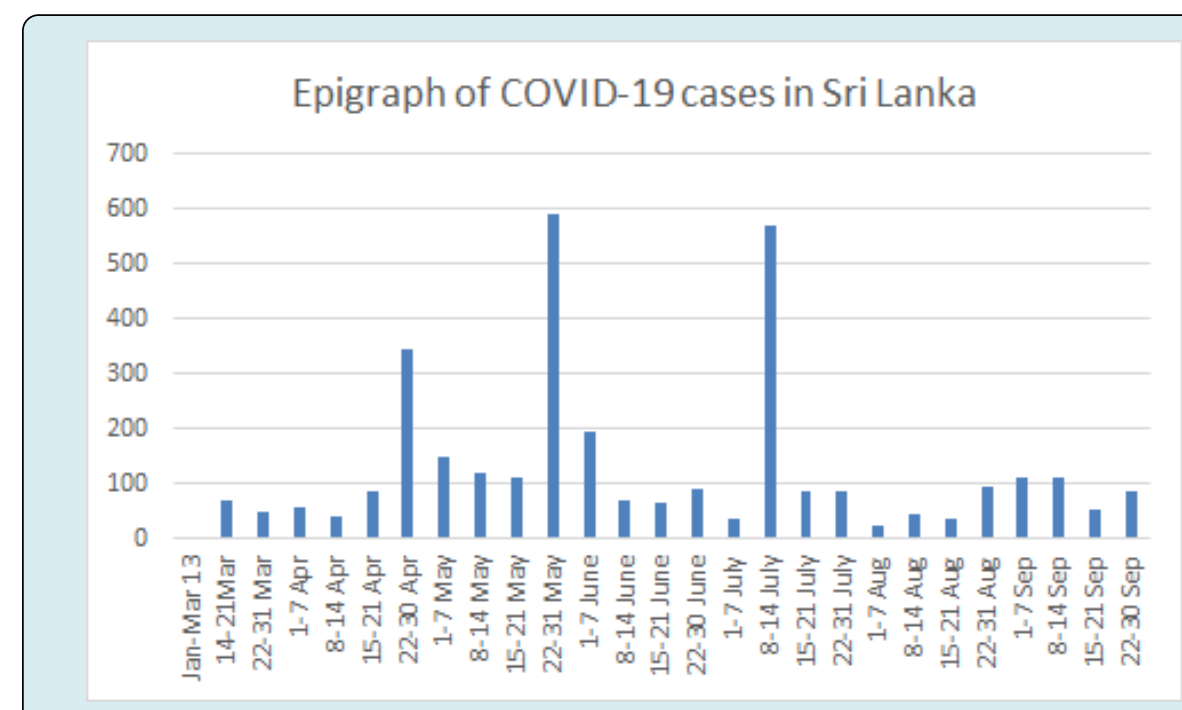

Figure 2: COVID- 19 New Cases in Sri Lanka from January to September 2020.

\section{Objectives}

This paper describes the efforts of Sri Lanka a LMIC in managing the first wave of COVID-19 pandemic to learn from shared experiences.

\section{Methodology}

This is an auto-ethnographic study where authors used their own experiences to extend understanding of pandemic management in a LMIC [8]. Eight Consultant Community 
Physicians holding key positions in Sri Lanka's pandemic management teams at the national or regional level were invited to be coauthors. Five members including the Chief Epidemiologist of Sri Lanka, two Regional Directors for Health services, and two Regional Epidemiologists agreed to be coauthors. Potential co-authors were contacted by email only once. These co-authors were asked to describe their experiences as written or participate in interviews which were recorded and transcribed. The hospital Research Ethics Board approved the study. All narratives were synthesized into a master narrative organized thematically to capture of main strategies employed in managing the pandemic.

\section{Results}

Pandemic management is described under four themes: Surveillance and public health activation; Test, isolate and trace strategy; Infection prevention and control strategy; Communication strategy. Quotes describing a summary of activities are presented on Table 1.

\begin{tabular}{|c|c|}
\hline Strategy & Quotes describing activities \\
\hline $\begin{array}{l}\text { Early preparedness and risk } \\
\text { communication }\end{array}$ & $\begin{array}{l}\text { "The Epidemiology Unit was on alert well in advance. The guidelines were issued on 26.01. } \\
2020 \text { even before the first case was diagnosed based on Influenza preparedness and WHO } \\
\text { guidelines" }\end{array}$ \\
\hline $\begin{array}{l}\text { Action committee with } \\
\text { multiple partnerships }\end{array}$ & $\begin{array}{l}\text { "From the beginning the health sector received support from political leadership, army, } \\
\text { police, State intelligence services, government administrative authority and community". }\end{array}$ \\
\hline \multirow{3}{*}{ Securing ports of entry } & $\begin{array}{c}\text { "From Late January health declaration was collected from returnees through airports later } \\
\text { extended to seaports. also they were checked with thermal scanners" }\end{array}$ \\
\hline & $\begin{array}{l}\text { 'Airports were shut down in Mid-March, later restricted flight operations initiated. We } \\
\text { initiated on arrival PCR testing for returnees since June". }\end{array}$ \\
\hline & $\begin{array}{l}\text { "Further international and local sailors sent for } 14 \text { days quarantine before entering the } \\
\text { society. Changing vessels happened before mandatory } 14 \text { days quarantine period. This was } \\
\text { because if a sailor misses his scheduled vessel he will have to wait extended period until } \\
\text { new assignment is received". }\end{array}$ \\
\hline \multirow{2}{*}{$\begin{array}{l}\text { Identification of high risk } \\
\text { geographical areas }\end{array}$} & $\begin{array}{c}\text { "We paid more attention on Western province with main international airport, harbour and } \\
\text { been the commercial hub and residence to a quarter of the population of the country". }\end{array}$ \\
\hline & $\begin{array}{c}\text { "North-Western province experienced many Middle-Eastern migrant workers returning due } \\
\text { to loss of jobs, "mini-Italy" with considerable number of returnees with the tense situation } \\
\text { in Italy and some Chinese employees returning after vacation" }\end{array}$ \\
\hline \multirow{2}{*}{$\begin{array}{l}\text { Early preparedness and for } \\
\text { PCR testing }\end{array}$} & $\begin{array}{c}\text { "We were able to establish PCR testing facilities before the first case within the country with } \\
\text { the help of Hong Kong University". }\end{array}$ \\
\hline & $\begin{array}{l}\text { "Gradually many hospitals were given PCR testing facilities and increased the numbers } \\
\text { beyond } 2500 \text { samples a day with results on the same day and free of charge" }\end{array}$ \\
\hline \multirow{2}{*}{$\begin{array}{l}\text { All positive patients admitted } \\
\text { to hospitals }\end{array}$} & $\begin{array}{l}\text { "Our strategy was different we admitted all positive patients to hospitals or COVID } \\
\text { treatment centers irrespective of the severity". }\end{array}$ \\
\hline & $\begin{array}{c}\text { "Some hospitals were refurbished or different buildings converted to treatment centers with } \\
\text { the help of the military" }\end{array}$ \\
\hline \multirow[t]{2}{*}{ Contact tracing } & $\begin{array}{l}\text { "All positive results by the labs urgently informed through phone to the Epidemiology unit, } \\
\text { they obtain contact and travel history by phone. This information is urgently conveyed to } \\
\text { District Epidemiology teams, Regional Epidemiologist and Medical Officer of Health (MOH) } \\
\text { teams to locate contacts and quarantined them in homes or centers" }\end{array}$ \\
\hline & $\begin{array}{c}\text { "State intelligence service also supplement information on patients recent movements and } \\
\text { contacts which was very helpful, further they monitored people in house quarantine to see if } \\
\text { they adhere" }\end{array}$ \\
\hline
\end{tabular}




\begin{tabular}{|c|c|}
\hline \multirow{4}{*}{$\begin{array}{l}\text { Self- isolation, quarantine, } \\
\text { lock down and curfew }\end{array}$} & $\begin{array}{l}\text { "Initially returnees from China, South. Korea, Iran, Italy and later from all countries were } \\
\text { subjected to home isolation and PCR testing if developed symptoms". }\end{array}$ \\
\hline & $\begin{array}{l}\text { Institutionalised quarantine started as some persons didn't adhere to advice and due to } \\
\text { overcrowding of houses". }\end{array}$ \\
\hline & $\begin{array}{l}\text { "Some densely populated neighbourhoods were completely lock downed when the entire } \\
\text { community seems to be exposed to patients". }\end{array}$ \\
\hline & $\begin{array}{l}\text { Schools, universities and work places gradually closed down with several public holidays } \\
\text { initially with reporting of cases and extended to curfews in high risk areas and finally, to } \\
\text { entire country. During this time many were given the option of work from home" }\end{array}$ \\
\hline \multirow[t]{2}{*}{$\begin{array}{l}\text { District level preparedness } \\
\text { and activities }\end{array}$} & $\begin{array}{c}\text { "District health committee were formed headed by Regional Director of Health Services, } \\
\text { with a team of public health physicians including Consultant Community Physician, Regional } \\
\text { Epidemiologist, and Medical Officer of Maternal and Child Health. They were responsible for } \\
\text { preparing health institutions and staff training for the pandemic". }\end{array}$ \\
\hline & $\begin{array}{c}\text { "Health institutions were modified for patient triaging, isolation, sample collection, facilities } \\
\text { for hand washing and social distancing with the available minimal resource" }\end{array}$ \\
\hline \multirow{3}{*}{$\begin{array}{l}\text { Local level/Field level } \\
\text { activities }\end{array}$} & $\begin{array}{l}\text { "MOH teams carried out contact tracing, home quarantine and follow up and coordination of } \\
\text { patient transportation from houses". }\end{array}$ \\
\hline & $\begin{array}{l}\text { "PHIs visited supermarkets, workplaces and other high risk public places and displayed } \\
\text { posters on disease preventive measures. Using public address systems public awareness } \\
\text { was conducted". }\end{array}$ \\
\hline & $\begin{array}{l}\text { "Routine hospital clinic services were disrupted and nationwide programme launch to } \\
\text { collect clinic books from homes and deliver drugs to doorstep; This was successful although } \\
\text { we have never tried this activity before". }\end{array}$ \\
\hline \multirow{2}{*}{ Communication } & $\begin{array}{c}\text { "The new concept of virtual meetings was welcomed by officials to coordinate activities } \\
\text { among national, district level and local authorities". }\end{array}$ \\
\hline & $\begin{array}{c}\text { "Social media platforms used to communicate among health staff groups at institution and } \\
\text { district level". }\end{array}$ \\
\hline
\end{tabular}

Table 1: COVID-19 control strategies practiced in Sri Lanka.

\section{Surveillance and Public Health Actions}

The Epidemiology unit issued guidelines based on WHO guidelines on January 26, 2020 in advance to reporting the first case. In parallel, a Presidential Action Committee chaired by the Health Minister was created in late January, with representation from the health sector (the Director General of Health Services, Chief Epidemiologist and healthcare leaders), political leadership (the Governor of Western province) and the Armed forces. The Police Department and local government services were added later to contain the pandemic. Airports were closed in mid-March but Sri Lankans were allowed to return in a controlled manner. The public were instructed to use the existing free government ambulance service with toll- free $24 / 7$ hotline to transport patients to health institution and another free hotline to contact physicians for advice was established. International students and workers stranded in Middle Eastern countries were priority repatriation groups. Repatriation of 33 students from Wuhan was the first mission where the airline staff followed infection prevention strategies including changing clothes on disembarkation, disinfecting belongings and being quarantined for 14 days in a quarantine center. None of the staff or passengers was infected. Many Middle East returnees were infected with SARS CoV-2 when tested on arrival.

Repatriation was influenced by the availability of quarantine accommodation. Health declaration forms completeness was a challenge and some people did not adhere to home quarantine guidelines. All returnees were sent to compulsory institutionalised quarantine for 14 days as of March 10, 2020. Initially, quarantine accommodations were provided free of charge at governmental facilities to citizens and foreigners. Later, there was an option to be quarantined at designated hotels at reasonable rates. Currently, accommodations are available for 8000 persons at a given time in free and paid quarantine centers. Sri Lankan commercial sailors were allowed to return to their residences, after 14 day quarantine. Sailors were allowed to board ships for their next assignment and exempted the 14day quarantine at times. International seafarers were paid 
by their companies for quarantine facilities. The Western province, a popular touristand commercial hub was identified as a high- risk- area for community-spread of COVID-19. Another district called Putlam in the North-Western province, a crucial area that provided salt, vegetables, fish, and poultry to the country, was also identified as a high- risk- area as there were many Chinese workers in addition to returnees from the Middle-East and Italy.

\section{Testing, Isolation and Tracing}

Sri Lanka established Polymerase-Chain- Reaction (PCR) testing at the Medical Research Institute with support from the University of Hong Kong and was able to test the first patient within 24 hours after admission. Testing facilities were expanded at hospitals with virologists or bacteriologists. The Dengue Research Laboratory at a university started PCR testing and other universities joined later. The Institute of Nanotechnology manufactured viral swabs locally at one third of importing cost to mitigate the shortage of viral swabs. Private hospitals were allowed to do PCR testing after cost regulations were implemented. Test results had to be available within 24 hours and suspected patients had to be admitted until results were available.

The testing strategy changed from test only "symptomatic cases" of persons in quarantine to "all suspected contacts" on March 30, 2020. Sri Lanka continues to admit all PCR positive patients to COVID treatment centers irrespective of severity of disease until article submission on September 23, 2020. The National Institute of Infectious Disease Hospital had 384 beds to handle an epidemic but most of the isolation wards and rooms in other General Hospitals had to be quickly modifies to properly isolate patients. COVID-19 patient triaging, PCR testing, treatment and isolation were carried out under the supervision of clinical consultants in 14 selected hospitals initially and expanded to 30 hospitals and COVID -19 treatment centers. Two previously closed hospital buildings and an abandoned radio station in a high risk area were rapidly refurbished and converted to COVID-19 specialised treatment centers.

Since the first case identification, high risk persons continued to be tested and the second case was identified on March 11, 2020. Contact tracing was initiated and coordinated by the Central Epidemiology Unit and respective District Epidemiology teams after the first reported local case. Since all suspected persons were hospitalised public health officials were able to communicate with them and obtain travel history for contact tracing. State Intelligence services supplement information on recent movement of cases and contacts. District Regional and $\mathrm{MOH}$ teams to locate contacts and quarantine. Public Health Inspectors monitored quarantined persons and transported symptomatic patients to hospitals. Each patient's information was maintained as a paper file centrally at the epidemiology unit. A list of quarantined patients in each of $\mathrm{MOH}$ areas is updated daily by the $\mathrm{MOH}$ and monitored by Regional Epidemiologists and Consultant Community Physicians. The information is shared electronically among MOHs and hospitals in the district.

\section{Infection Prevention and Control Strategy}

Heads of health institutions had to organize triage areas, isolation rooms, personal protective equipment, staff training and other logistic issues. Although ideal triage and isolation facilities were difficult to setup in rural areas, available resources were maximized to ensure social distancing. Many staff prepared their own personal protective equipment (PPE) using locally available material such as cloth for masks and clear plastic sheets for face shields. The community and non-governmental organizations donated PPEs, food and other essential to hospitals. Hand washing facilities, masking and social distancing instructions were displayed on all outpatient areas and public address systems and videos were used to give further instructions. Health Education and Infection Control Nursing Officers facilitated patient awareness and education at hospital outpatient departments (OPD). Pregnant mothers were educated at clinics and in the field by Public Health Midwives. It was challenging to continue necessary maternal health services in the field, especially when mothers of quarantined houses needed medical attention. MOH team's coordination with other stakeholders such as the District Secretary, Deputy Inspector General of Police, higher officials as needed for relevant field activities. COVID-19 infection as occupational exposure was only seen among a few healthcare and other workers in Quarantine Centers or at the airport directly handling passengers. Health care workers and other staff who had "suspected exposure" were quarantined and tested in addition to regular random testing among asymptomatic staff in quarantine centers.

At the outset PCR testing was performed for all suspected cases and only for symptomatic contacts. Primary or secondary contacts of a positive case were cleared of surveillance after 14 day house quarantine if asymptomatic. In April Sri Lanka started testing all contacts. The military played a large role in setting up quarantine centers by mobilising their manpower and setting up quarantine centers at military camps, government buildings and naval ships as needed. Home quarantine, self- isolation and physical distancing were not always possible as many homes in Sri Lanka were small and shared by many family members. As such, establishing quarantine centers was undertaken to avoid community spread. In certain communities shared toilets and backyards made self-isolation difficult and in some communities communal eating was enabling the rapid spread of the disease. Therefore high risk contacts in such 
areas were also sent to quarantine centers.

When a couple of isolated cases were found in crowded urban areas in the Western province, there was complete lock down, isolating the risk areas and spread of the disease was confined to small neighbourhoods. Schools and universities were closed in mid-March. A few of public holidays were given to keep people at home which were extended to a curfew in some high risk areas. Curfews were enforced in the whole country since the third week of March. As inter-district travel was also banned some people who had travelled for jobs, medical treatment, and family events were stranded in other districts. Curfews violators were arrested and vehicles impounded. There was mass media campaign to adhere to curfews or risk of prosecution. The police played a major role to control public movement in cities. Although there was some public movements in rural areas, the risk was negligible. The health sector did not advocate masks for the general public due to an initial lack of clear evidence and absence of community transmission. However, the police implemented a strict policy to wear masks in public. With the reopening of country health officials advised public to wear masks.

\section{Communication Strategy}

Effective means of communication within the healthcare system, other sectors involved in pandemic management and the public was essential for the entire process. Online meetings were introduced to coordinate activities among national and district level authorities and it was time saving for $\mathrm{MOH}$ and district staff to coordinate via ZOOM meetings. A communicator was designated to inform guidelines to health institutions and to convey the needs of institutions to district authorities. Social media groups were created among health workers and institutional heads to update latest information on guidelines, issues, and up-to-date status reports. District Secretary, Deputy Inspector General of Police and officials in the Armed forces worked very closely with district health teams as needed to provide basic supplies to communities under lockdown. Following curfew declarations, this network was extended island wide to provide food, medicine and even mobile banking facilities. MOH teams provided technical guidance for social distancing and infection prevention strategies for such activities.

Mass media repeatedly promoted the importance of infection prevention strategies such as social distancing, masks, quarantine created to change the public behavior and keep them indoors. The public were educated to the difference between quarantine and isolation to alleviate phobias about quarantine and reluctance to self-isolate. The district health authorities received significant support from the community and religious leaders in managing the pandemic. PHIs visited supermarkets, workplaces and other high risk public places and displayed posters on disease preventive measures, hand washing and health habits. Public awareness was conducted at the community level by all $\mathrm{MOH}$ offices using public address systems. People didn't have much option to ignore public health recommendations as this was a multi-sectoral programme. If they do not comply with PHI, the police and the government agent got involved.

\section{Challenges and Solutions}

There had been many challenges ranging from a lack of PPE to economic impact of lockdowns and other measures implemented to contain the pandemic. Authors' description of some of these is summarized on Table 2 and potential lessons from this pandemic are presented in Table 3.

\begin{tabular}{|c|c|}
\hline Challenge & Quotes \\
\hline \multirow{4}{*}{$\begin{array}{c}\text { Lack of Personal } \\
\text { Protective Equipment } \\
\text { ( PPE) }\end{array}$} & $\begin{array}{c}\text { "Severe shortage of PPE was experienced at the beginning. Except for N95 masks most other } \\
\text { PPE were prepared locally by staff and community. Some improvised plastic bags initially } \\
\text { as protective aprons." "One of the Universities designed simple helmet like wiser to prevent } \\
\text { healthcare workers from droplets and a Technical Training Institute produced 700 of them using } \\
\text { laser cutters and 3D printers within two days." "Isolation rooms were partitioned by polythene } \\
\text { sheets; some hospitals used a glass shield between patient and doctor. Somehow all hospitals } \\
\text { managed to maintain minimal contamination using various methods." }\end{array}$ \\
\cline { 2 - 2 } & $\begin{array}{c}\text { "Initially some healthcare workers tried to stay away from potential COVID patients. However, } \\
\text { after some time they followed necessary infection prevention precautions and by the time when } \\
\text { cluster of Navy officers were infected, they had visited the hospitals before knowing they were } \\
\text { infected. At that time hospital staff confidently stated they have not been exposed as they were } \\
\text { following proper PPE precautions." }\end{array}$ \\
\hline
\end{tabular}




\begin{tabular}{|c|c|}
\hline \multirow{2}{*}{$\begin{array}{c}\text { Challenges to Contact } \\
\text { Tracing }\end{array}$} & $\begin{array}{l}\text { "With the increase number of positive cases being reported, contact tracing was a challenge to } \\
\text { the MOHs with inadequate PPE, transport facilities and meals for the field health staff as the } \\
\text { district were under curfew." }\end{array}$ \\
\hline & $\begin{array}{l}\text { "The PPE were obtained from the Health Ministry and donors. Extra vehicles and staff for high } \\
\text { risk MOH areas were mobilized from low risk MOH areas. Internal arrangements were made to } \\
\text { provide meals for the staff who were virtually doing a } 24 / 7 \text { duty." }\end{array}$ \\
\hline \multirow{2}{*}{$\begin{array}{c}\text { Quarantine } \\
\text { accommodations }\end{array}$} & $\begin{array}{c}\text { "Sri Lankan returnees, originally from China, South. Korea, Iran. Italy and later from all countries } \\
\text { were subjected to PCR testing while in home isolation. When many of Italian returnees tested } \\
\text { positive and when it seems that self- isolation was not properly practiced, it was decided by } \\
\text { health authorities to set up quarantine facilities. A vacant Leprosy hospital closer to Colombo } \\
\text { was initially identified, however that plan was abandoned due to unrest among neighboring } \\
\text { residents." }\end{array}$ \\
\hline & $\begin{array}{l}\text { "When a returnee from Indonesia was found positive, it was a challenge to home quarantine his } \\
70 \text { contacts. The health authorities with the support of the Urban Council, Divisional Secretary, } \\
\text { Army and the Police converted a school into a quarantine center with required facilities. Due to } \\
\text { stringent measures taken in early identification, isolation and quarantine spread was prevented } \\
\text { further." }\end{array}$ \\
\hline $\begin{array}{l}\text { Healthcare access for non } \\
\text { COVID cases }\end{array}$ & $\begin{array}{c}\text { "The outpatient departments (walk in outpatient care) continued to function in all hospitals } \\
\text { but the clinics were closed. However, fear of COVID-19 and curfews deterred many people from } \\
\text { seeking healthcare." }\end{array}$ \\
\hline $\begin{array}{l}\text { Access to medications for } \\
\text { chronic illness }\end{array}$ & $\begin{array}{l}\text { "The health staff with the support of the other sectors delivered the medicine to the clinic } \\
\text { patients" homes. With the Epidemic, all routine screening, clinics and surgical activities were } \\
\text { disrupted. It was a challenge to deliver the long- term- use drugs to the existing patients. } \\
\text { A national Level decision was taken to deliver the drugs to the patient door step. Different } \\
\text { strategies were adopted at this stage. The village public administrative officers called (Gram } \\
\text { Niladhari) collected the clinic books carried by patients and sent them to the hospital } \\
\text { dispensary. The packed drugs for } 2 \text { months were delivered back to patients either by the } \\
\text { same official or by Public health Inspector or by the mailman. Although SL had not previously } \\
\text { had a drug delivery system it turned out to be a successful intervention. Dispensary statistics } \\
\text { confirmed majority of the patients have received drugs by some means. However patients could } \\
\text { not be seen and routine checking such as blood pressure monitoring were not done prior to } \\
\text { medication dispensing." }\end{array}$ \\
\hline Antenatal care & $\begin{array}{l}\text { "Antenatal care was limited to high risk mothers and mothers above } 36 \text { weeks. Immunization } \\
\text { was stopped during the high-risk period and resumed after } 28 \text { days of the detection of last } \\
\text { positive case from Puttlam district. Family health Bureau and Sri Lanka Collage of Obstetricians } \\
\text { and Gynecologists were called for advice and a separate hospital equipped with proper facilities } \\
\text { was identified to send high risk pregnant mothers." }\end{array}$ \\
\hline Social Stigma & $\begin{array}{l}\text { "At the beginning there was a huge social stigma associated with the people coming from high } \\
\text { risk areas even among health workers. In general, hospital staff is informed before sending a } \\
\text { patient from a high risk area. Hospitals were initially reluctant to accept pregnant patients from } \\
\text { high risk areas due to inadequate supply of PPE for health workers and the risk of spreading the } \\
\text { disease to the other mothers in the hospital." }\end{array}$ \\
\hline $\begin{array}{l}\text { Economic impact of } \\
\text { lockdowns }\end{array}$ & $\begin{array}{l}\text { "All these control measures to contain the spread came at an economic cost. Many people in } \\
\text { Sri Lanka live on daily earnings and their livelihood was completely shut down because of the } \\
\text { curfew. It is correct to stop foreigners coming to the country to prevent virus entering to the } \\
\text { country but the whole economy shut down. People wondered if their strategy or the way the } \\
\text { western world tackled the disease was more cost effective. Government subsidy of Rs.5000/ } \\
\text { (about USD 29) per family in the low income category was grossly inadequate for urban dwellers } \\
\text { although sufficient for rural dwellers." }\end{array}$ \\
\hline
\end{tabular}




\begin{tabular}{|c|c|}
\hline \multirow[t]{3}{*}{$\begin{array}{l}\text { Containing Cluster } \\
\text { spreads }\end{array}$} & $\begin{array}{l}\text { "When the cases were reaching almost to zero level a naval officer who had helped with } \\
\text { quarantine presented with symptoms to one of the hospitals confirmed positive. At this time, } \\
\text { more than a thousand naval service personal from the same camp and many more from all } \\
\text { military camps were sent on vacation to prevent overcrowding as per government instructions. } \\
\text { Following identification of the outbreak, instructions were given to all Regional Epidemiologist } \\
\text { to house quarantine family members of all armed forces who had gone home. All military } \\
\text { personnel were called back and quarantined in schools that were vacant. Within the first } \\
\text { few days } 80 \text { navy personals and } 40 \text { family members tested positive and with the quick action } \\
\text { community spread was prevented beyond family members. Nevertheless, disease had been } \\
\text { spreading in two navy camps asymptomatically similar to a free community spread and it was a } \\
\text { difficult task to contain the disease. Measures were taken to thin out population by sending them } \\
\text { to quarantine centers. With numerous measures it became the largest cluster over } 950 \text { cases and } \\
\text { took more than two months to contain the disease within this cluster." }\end{array}$ \\
\hline & $\begin{array}{l}\text { "On July 8th when the Navy cluster was settling two inmates from a large prison in the Western } \\
\text { Province tested positive for COVID-19. The index case had been transferred from a large } \\
\text { rehabilitation center (from Polonnaruwa). Testing staff, patients and contacts identified } 300 \\
\text { cases, the highest number of cases in a single day. Although no clear evidence was found how the } \\
\text { disease entered the center it is believed an asymptomatic carrier from the nearby quarantine } \\
\text { center might have contracted the disease. Being a residential institution risk of community } \\
\text { spread was minimal, yet several of staff members on vacation were found to be positive. }\end{array}$ \\
\hline & $\begin{array}{l}\text { All family members and close contacts were quarantined within houses. It developed in to a } \\
\text { cluster of } 549 \text { residents and } 52 \text { close contacts and by end of July this cluster settled." }\end{array}$ \\
\hline \multirow[b]{2}{*}{ Reopening the country } & $\begin{array}{l}\text { "There was considerable pressure from small businesses to go back to normal and restricted } \\
\text { opening of country was started in a controlled manner. Private and Government offices are } \\
\text { opening up with limited number of persons attending to work with night curfew initially. } \\
\text { Transport facilities were also limited and only allowed to be used by the working community." }\end{array}$ \\
\hline & $\begin{array}{l}\text { "Gradually schools are being reopened initially (Mid July) with limited number of hours for } \\
\text { students to be in schools and full schools as of mid-August. Sri Lanka started opening the } \\
\text { airports in August for repatriates and limited number of foreigners in development projects/ } \\
\text { business and diplomats only. Tourist is not allowed still. National elections conducted on August } \\
\text { 5, } 2020 \text { with infection prevention control measures. With reopening of the country is a high } \\
\text { chance of disease re-entering the country." }\end{array}$ \\
\hline
\end{tabular}

Table 2: Challenges during pandemic management.

Important Lesson From COVID-19 Pandemic Management

Establishment of action committees, chain of command and communication channels and systems Securing the borders or entry points, identifying vulnerable areas and or populations early to start surveillance Collaboration with hospitals, universities and research institution to make testing available within a short turnaround time (TAT). Monitoring private testing for quality, cost and timeliness.

Testing, isolating all positive cases and active \& extensive contact tracing. Modifying hospitals and institutions to isolate patients and ensuring adequate PPE is available for staff. Creating quarantine centers.

Partnering with other sectors to implement infection prevention and control measures, getting community buy in and locking down the country if needed.

Table 3: Important Lesson from COVID-19 Pandemic Management.

\section{Discussion}

The global response to the COVID-19 pandemic has been reported as suboptimal [9]. There was concern that
COVID-19 pandemic will devastate LMICs and lead to high mortality in older people [10]. Emphasis on six factors to contain COVID-19 in LMICs such as :Laboratory diagnosis and subtyping; surveillance, including screening at points of 
entry and cross-border activities; infection prevention and control in healthcare facilities; clinical treatment of people with severe COVID-19; risk communication; and supply chain management and stockpiles are suggested [11]. WHO advises to ensure that minimum requirements for infection prevention and control are in place and to form media partnerships to prevent societal fear [12].

Sri Lanka seems to have followed similar measures and additional strategies such as strict infection control measures, extensive collaboration and a test, isolate and trace strategy which seemed to have contained the spread so far. While supply chain for PPE was a problem, institutions, departments and health workers were allowed to source their own PPE and locally produced personal protective equipment were used in hospitals. This is in contrast to the developed countries where healthcare workers were penalized for wearing masks if they were considered nonclient facing or wearing them in non-clinical areas during the early stages of pandemic [13]. Although, cloth masks have been shown to be inferior to $\mathrm{N} 95$ and surgical masks in providing protection, they are reported to aid in infection control $[14,15]$.

China initially showed that coordinated public health responses during an outbreak can contain COVID-19 [16], and infection prevention seems to be the most effective way of controlling COVID-19 in LMICs [17]. As of July 8, 2020 (until the drug rehabilitation cluster developed) $78 \%$ of PCR tested patients in Sri Lanka were found to be asymptomatic [7]. This is identical to the results from China reporting that $78 \%$ of positive cases were asymptomatic [18].

There is limited literature on managing asymptomatic patients and the efficacy of home isolation has been questioned recently [19]. Italy reported pandemic containment by identifying and isolating positive cases in a village [20]. This paper describes the effects of admission and isolation of asymptomatic COVID- 19 patients in a LMIC and illustrates that effective infection control practices are possible in low middle income countries to contain a pandemic. It is noteworthy that national elections were held in August and schools are reopened with minimal infection spread. Authors believe that this paper and measures described will be useful to inform other countries and health systems dealing with COVID pandemic management and caution that the effectiveness of all control measures will depend on early detection of cases and containment of the second wave if it happens.

\section{Conclusion}

Sri Lanka's pandemic management seems to have helped COVID-19 containment to population clusters for the first wave. An established public health network in Sri Lanka in addition to a publicly funded and publicly delivered healthcare service facilitated a coordinated approach.

\section{References}

1. WHO (2020) WHO statement regarding cluster of pneumonia cases in Wuhan, China. World Health Organization.

2. Kumar R (2019) Public-private partnerships for universal health coverage? The future of "free health" in Sri Lanka. Globalization and Health 15(1): 1-10.

3. IPS Research Team (2018) Sending Sri Lankans and Receiving Chinese Workers: Emerging Trend of Labour Migration in Sri Lanka.

4. (2019) Sri Lanka to issue free visas for Chinese tourists. China Daily.

5. (2020) Novel Coronavirus (2019-nCoV) - Situation Report. Epidemiology Unit Ministry of Health.

6. (2020) COVID-19 Dashboard by the Center for Systems Science and Engineering (CSSE) at Johns Hopkins University.

7. (2020) Coronavirus disease 2019 (COVID-19) - Situation Report.

8. Holt NL (2003) Representation, legitimation, and autoethnography: An autoethnographic writing story. International journal of qualitative methods 2(1): 18-28.

9. (2020) COVID-19: too little, too late? Lancet 395(10226): 755.

10. Lloyd-Sherlock P, Ebrahim S, Geffen L, McKee M (2020) Bearing the brunt of covid-19: older people in low and middle income countries. BMJ.

11. Nkengasong JN, Mankoula W (2020) Looming threat of COVID-19 infection in Africa: act collectively, and fast. Lancet 395(10227): 841-842.

12. Hopman J, Allegranzi B, Mehtar S (2020) Managing COVID-19 in low-and middle-income countries. JAMA 323(16): 1549-1550.

13. Chethan S (2020) Why Would Hospitals Forbid Physicians and Nurses from Wearing Masks? Scientific American.

14. Qaseem A, Etxeandia II, Yost J, Miller MC, Abraham GM, et al. (2020) Use of N95, Surgical, and Cloth Masks to Prevent COVID-19 in Health Care and Community 
Settings: Living Practice Points From the American College of Physicians (Version 1). Ann Intern Med 173(8): 642-649.

15. Vander SM, Teunis P, Sabel R (2008) Professional and Home-Made Face Masks Reduce Exposure to Respiratory Infections among the General Population. PLoS One 3(7): e2618.

16. Wu Z, McGoogan JM (2020) Characteristics of and Important Lessons From the Coronavirus Disease 2019 (COVID-19) Outbreak in China: Summary of a Report of 72314 Cases From the Chinese Center for Disease Control and Prevention. JAMA 323(13): 1239-1242.
17. Khadka S, Hashmi FK, Usman M (2020) Preventing COVID-19 in low-and middle-income countries. Drugs \& Therapy Perspectives, pp: 1-3.

18. Day M (2020) Covid-19: four fifths of cases are asymptomatic, China figures indicate. BMJ 369: m1375.

19. Haroon S, Chandan JS, Middleton J, Cheng KK (2020) Covid-19: breaking the chain of household transmission. BMJ 370: m3181.

20. Day M (2020) Covid-19: identifying and isolating asymptomatic people helped eliminate virus in Italian village. BMJ 368: m1165. 